\title{
Coverage of genomic medicine: information gap between lay public and scientists
}

\author{
This article was published in the following Dove Press journal: \\ Risk Management and Healthcare Policy \\ I August 2012 \\ Number of times this article has been viewed
}

\section{Yuya Sugawara' \\ Hiroto Narimatsu ${ }^{2,3}$ \\ Akira Fukao 2,3 \\ 'Department of Medical Informatics, Graduate School of Medical Science, Yamagata University, Yamagata, ${ }^{2}$ Advanced Molecular Epidemiology Research Institute, Faculty of Medicine, Yamagata University, Yamagata, ${ }^{3}$ Department of Public Health, Yamagata University Graduate School of Medicine, Yamagata, Japan}

Correspondence: Hiroto Narimatsu Advanced Molecular Epidemiology Research Institute, Faculty of Medicine, Yamagata University, 2-2-2 lida-nishi, Yamagata, Yamagata 990-9585, Japan

Tel +8I 0236285260

Fax +8I 0236285261

Email hiroto-narimatsu@umin.net

\begin{abstract}
The sharing of information between the lay public and medical professionals is crucial to the conduct of personalized medicine using genomic information in the near future. Mass media, such as newspapers, can play an important role in disseminating scientific information. However, studies on the role of newspaper coverage of genome-related articles are highly limited. We investigated the coverage of genomic medicine in five major Japanese newspapers (Asahi, Mainichi, Yomiuri, Sankei, and Nikkei) using Nikkei Telecom and articles in scientific journals in PubMed from 1995 to 2009. The number of genome-related articles in all five newspapers temporarily increased in 2000, and began continuously decreasing thereafter from 2001 to 2009. Conversely, there was a continuous increasing trend in the number of genome-related articles in PubMed during this period. The numbers of genomerelated articles among the five major newspapers from 1995 to 2009 were significantly different $(P=0.002)$. Commentaries, research articles, and articles about companies were the most frequent in 2001 and 2003, when the number of genome-related articles transiently increased in the five newspapers. This study highlights the significant gap between newspaper coverage and scientific articles in scientific journals.
\end{abstract}

Keywords: coverage, personalized medicine, mass media, newspaper

\section{Introduction}

In the wake of the Human Genome Project, ${ }^{1,2}$ which has mapped the entire human DNA sequence, genomic medical research has entered a new era. A working draft of the genome was announced in 2000 and the complete DNA sequence was announced in 2003. In particular, one of the major challenges for medical research in the first half of the 21 st century is to develop preventive and therapeutic measures against various diseases by clarifying their relationships with respect to the patterns of human genetic variability.

Personalized medicine using genomic information, which takes into consideration the patient's genetic characteristics and history of environmental factors, is expected to catalyze the next generation of therapy, with the potential to provide preventive and curative interventions specific to each individual., ${ }^{3,4}$ Full-fledged personalized medicine will successfully personalize disease prevention efforts based on the available knowledge of each patient's specific risk factors. It will also adopt patient-specific practices, including the selection of pharmacotherapy tailored to the variations in an individual's pharmacogenetic/pharmacogenomic profile and risk of adverse drug reactions. Thus, personalized medicine is anticipated to reduce disease morbidity and mortality and improve therapeutic effectiveness, as well as impact other aspects of 
medical care. ${ }^{5-7}$ Since individual genomic information will be essential in fostering personalized medicine, lay people are required to possess accurate knowledge about genomic medicine - so-called "genomic literacy."

The role of mass media in sharing information about medical sciences is uncertain. Several studies have highlighted the importance of news media as a source of information about medicine and health; ${ }^{9-22}$ however, sharing of information about advanced science and medicine between academia and the mass media was reported as being difficult. Although the output of scientific papers increased by $15 \%$ between 1990 and 2001, with a total output over 650,000, fewer than $0.013 \%-0.34 \%$ of papers gained attention from the mass media. ${ }^{23}$

Given that newspaper coverage can include more information than other mass media such as television or radio, many medical professionals believe that newspapers are a suitable medium to disseminate information about genomic medicine; ${ }^{9}$ however, since studies on newspaper coverage are limited, the role of print media remains uncertain. In Japan, we have a unique and large newspaper database (Nikkei Telecom) that covers all articles in the five major national newspapers. In this study, we investigated newspaper coverage of genomic medicine in Japan.

\section{Methods}

\section{Objective of this study}

To examine the number of articles related to genomic medicine and their reported contents published by the five major Japanese newspapers within a 15-year time period (from 1995 to 2009), which is the time period covered by the newspaper database.

\section{Target newspapers}

This study was directed at the five major newspapers in Japan (Asahi, Mainichi, Yomiuri, Sankei, and Nikkei). The total number of subscribers to these newspapers was 26 million per day in 2010, indicating that $48 \%$ of households subscribed to these five newspapers in Japan. ${ }^{24}$

\section{Data extraction}

We extracted the articles using a keyword search of the database Nikkei Telecom, which is the largest newspaper database in Japan. This database incorporates almost all newspapers issued in Japan, including every article in the five major newspapers since 1995.
First, using a thesaurus search of the Igaku Chuo Zasshi database (Japan Medical Abstracts by NPO Japan Medical Abstracts Society), we extracted Japanese terms related to the word "genome" in order to define the following keywords: genome, human genome, Human Genome Project, genomic medicine, personalized medicine, made-to-order medicine, and tailor-made medicine. The contents of articles from 2001, 2003, and 2009 were analyzed by two researchers who are medical providers (YS and HN). Given the large number of articles, several of them could not be checked to ensure that the content pertained to genomic medicine and other relevant topics. The above-mentioned newspapers were subsequently searched for articles that contained these Japanese keywords, and annual changes in the numbers of such articles and their contents were investigated.

To quantify the number of genome-related research articles in academic journals, we conducted a PubMed search using the same keywords as above in English, and included the term "individualized medicine." The terms "genome, human," "Human Genome Project," and "individualized medicine" were indexed as Medical Subject Headings (MeSH). We also conducted a PubMed search using these MeSH terms.

We defined the terms "genomic medicine," "personalized medicine," "made-to-order medicine," "tailor-made medicine," and "individualized medicine" as genomic medicine-related keywords. Genomic medicine-related newspaper articles that were published in 2001 and 2003 - when the number of genomic medicine-related articles increased temporarily - and 2009, the most recent year, were extracted and categorized according to their contents.

\section{Statistical analysis}

Differences in the numbers of articles among the five newspapers were tested by a two-way ANOVA (newspapers $\mathrm{x}$ year), followed by Tukey's multiple-comparison post hoc test. R version 2.15.0 (R Foundation for Statistical Computing, Vienna, Austria) was used for all statistical analyses.

\section{Results}

\section{Total number of articles}

The total number of articles published in the five major newspapers in Japan (Asahi, Mainichi, Yomiuri, Sankei, and Nikkei) averaged 1,140,000 per year, including 280,000 in Asahi, 310,000 in Mainichi, 280,000 in Yomiuri, 130,000 in Sankei, and 140,000 in Nikkei. Figure 1 shows the change in the total number of articles across the five major newspapers during the study period. While the number of published articles has 


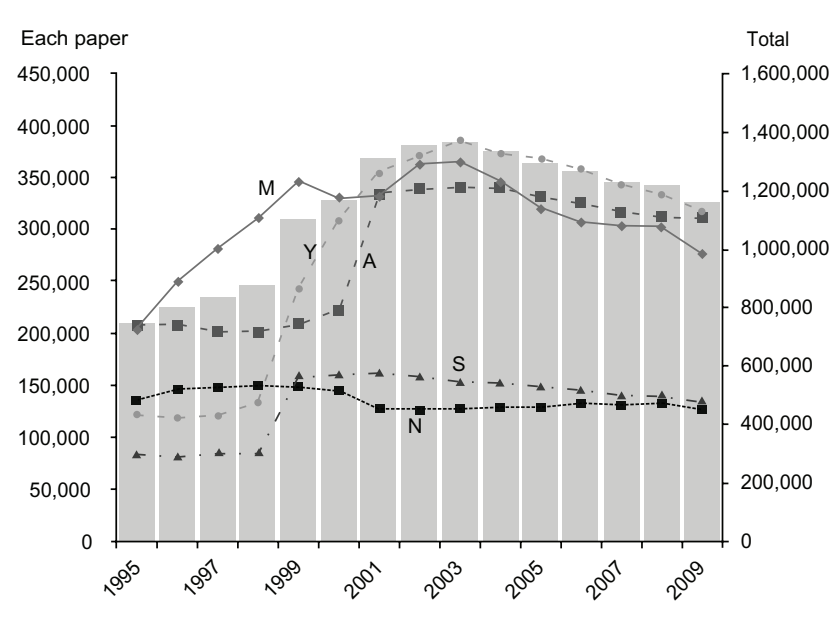

Figure I Total number of articles in five major newspapers.

Note: Bar: the five newspapers taken together.

Abbreviations: A, Asahi; M, Mainichi; Y, Yomiuri; S, Sankei; N, Nikkei.

increased since the early 1990 s, there has been almost no change since 2000. Since 2000, the total number of articles published in the Yomiuri, Asahi, and Mainichi newspapers has been approximately three times that in Nikkei and Sankei.

\section{Number of genome-related articles in the newspapers and genomic medicine- related scientific articles in PubMed}

From 1995 to 2009, the total number of genome-related articles published in the five newspapers was 16,735 , including 3019 in Asahi, 2583 in Mainichi, 3422 in Yomiuri, 3299 in Sankei, and 4412 in Nikkei. The numbers of articles containing the selected keywords in the five newspapers were: genome, $n=7518$; human genome, $n=4063$; Human Genome Project, $n=4310$; made-to-order medicine, $n=425$; tailor-made medicine, $n=336$; genomic medicine, $n=69$; and personalized medicine, $\mathrm{n}=14$.

Figure 2 shows the change in the number of genomerelated articles published in the five major newspapers. The trends in the number of newspaper articles related to the human genome (Figure 2A) and the Human Genome Project (Figure 2B) were almost the same, while the number of articles related to the human genome, the Human Genome Project, and those containing genomic medicine-related keywords, temporarily increased in 2000 across all five major newspapers. Conversely, articles containing genomic-medicine-related keywords (Figure 2C) demonstrated a unique trend: in 2003, the number of genomic-medicine-related articles published in Nikkei, Yomiuri, and Mainichi temporarily increased.

Figure 2 also shows the change in the number of genome-related articles published in PubMed. The trends in the number of human genome- (Figure 2A) and genomicmedicine-related articles in PubMed (Figure 2C) were the same; the number of human genome- and genomic-medicine-
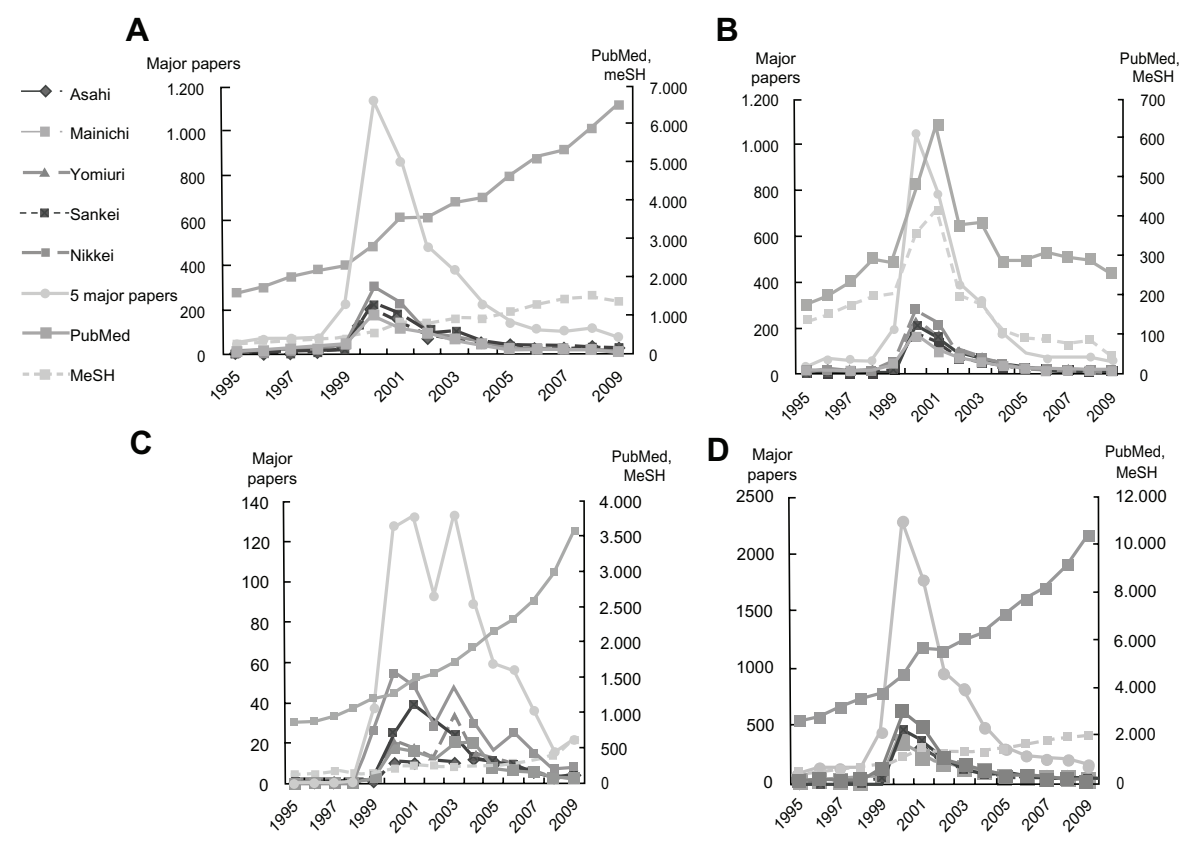

Figure 2 Number of genome-related articles in five major newspapers and genomic-medicine-related scientific articles in PubMed. (A) Articles related to human genome, (B) articles related to Human Genome Project, and (C) articles containing genomic medicine-related keywords in five major newspapers. A PubMed search using the following MeSH terms: "genome, human," "Human Genome Project," and "individualized medicine" was conducted in (A-C), respectively. The total number of articles related to $(\mathbf{A}-\mathbf{C})$ in the newspapers and PubMed are shown in (D).

Abbreviation: MeSH, Medical Subject Headings. 
related articles continuously increased. On the other hand, the number of articles related to the Human Genome Project (Figure 2B) showed a unique trend: the number of articles related to the Human Genome Project increased temporarily in 2001. The total number of articles containing all genomerelated keywords are shown in Figure 2D.

The numbers of genome-related articles that were published among the five major newspapers from 1995 to 2009 were significantly different $(P=0.002)$. Table 1 shows the comparison between the newspapers. Differences between Nikkei and Asahi $(P=0.04)$, and Nikkei and Mainichi $(P=0.001)$ were statistically significant.

\section{Contents of genomic medicine-related articles published in newspapers}

We investigated the contents of articles published in 2000, when the working draft of the genome was announced, and in 2003, when the complete genome was reported. We also investigated the contents of relevant articles published in 2009 , the most recent year available in the database. The number of genomic medicine-related articles was 132 in 2001, 133 in 2003, and 21 in 2009. The contents of genomic medicine-related articles in the newspapers and changes in content over the years are shown in Table 2. Commentary articles, articles about research, and articles about companies were most frequently published in 2001 and 2003 (86 articles in 2001 and 88 articles in 2003), when the number of genome-related articles transiently increased across the five newspapers.

\section{Discussion}

The present study shows that newspaper coverage about genomic medicine is usually transient. The number of such articles substantially, though temporarily, increased in 2001 (Figure 2). This is probably due to the fact that reports from the Human Genome Project were covered as one of the topics during this time period. In contrast, the rapid decrease after the transient increase in genome-related articles indicated

Table I Comparison of the number of genome-related articles in the five major newspapers*

\begin{tabular}{llllll}
\hline & Asahi & Yomiuri & Nikkei & Mainichi & Sankei \\
\hline Asahi & NA & - & - & - & - \\
Yomiuri & 0.83 & NA & - & - & - \\
Nikkei & 0.04 & 0.35 & NA & - & - \\
Mainichi & 0.71 & 0.15 & 0.001 & NA & - \\
Sankei & 0.92 & 1.00 & 0.24 & 0.23 & NA \\
\hline
\end{tabular}

Note: $* P$-values are shown.

Abbreviations: NA, not applicable; $P$, probability level. that detailed information about genomic medicine is not currently reported in newspapers. In contrast, the number of scientific articles about genomes or personalized medicine using genomic information that were found in PubMed has continuously increased, indicating that constant research and advances in genomic medicine have been occurring. This contrast reveals that there has been an information gap about genomic medicine as indicated in the findings noted between the mass media and scientists, and as described in other areas of advanced science. ${ }^{23}$ This gap might interfere with the dissemination of knowledge pertaining to genomic medicine, which may affect the conduct of related medical practices in the near future.

As previously reported, one characteristic feature of newspaper reporting on scientific issues is that only part of the subject matter is emphasized due to a poor balance in the number of news reports when compared to the number of scientific articles available. ${ }^{9,10}$ This would appear to be related to the amount of time it takes to discuss medical issues and to the fact that public interest drops when more detailed information or discussions appear. This is believed to be a structural problem inherent to the media, particularly with newspapers, which target the general public and report on a wide range of fields. This structural problem has already been recognized as an "issue attention cycle" in the United States, which was first described by Downs in $1972 .{ }^{11}$ This cycle has been observed and reported in relation to other medical issues, such as childhood obesity. ${ }^{12}$ In this cycle, public attention to a single issue is rarely sustained over an extended period, even in the case of critically important, unresolved problems. Scientists should be aware of this structural problem with mass media when they share information with the public. In this study, we did not investigate how much information is shared about other scientific topics; it would be worthwhile to investigate the newspaper coverage of these topics as well. In addition, the actual newspaper format might also have affected the results. Further, the influence of whether or not the newspaper carries a regular science section or employs science editors also needs to be considered when analyzing our results.

Although this study provided important information on the newspaper coverage of genomic medicine, the following issues still remain to be discussed. First, this study focused only on mass media. These days, the internet plays an increasingly important role in medical practice; information on the adverse effects of an anticancer drug, for example, was shared mainly by internet media such as blogs, homepages, and mail magazines between physicians, patients, pharmaceutical 
Table 2 Contents of genome-medicine related articles in the five major newspapers in Japan

\begin{tabular}{|c|c|c|c|c|c|c|}
\hline Classification & Detailed classification 200 I & $\mathbf{n}$ & Detailed classification 2003 & $\mathbf{n}$ & Detailed classification 2009 & $\mathbf{n}$ \\
\hline \multirow[t]{16}{*}{ Commentary } & Tailor-made medicine & 12 & Glossary & 4 & Gender-specific medicine & I \\
\hline & Glossary & 8 & Tailor-made medicine & 4 & $\begin{array}{l}\text { Nanotechnology and new } \\
\text { medical devices }\end{array}$ & I \\
\hline & Genes, SNPs, and gene therapy & 6 & $\begin{array}{l}\text { Announcement of sequencing } \\
\text { of the complete human genome }\end{array}$ & 2 & & \\
\hline & Genomic drug discovery & 5 & $\begin{array}{l}\text { Meaning and benefits of } \\
\text { deciphering the human genome }\end{array}$ & 2 & & \\
\hline & Regenerative medicine & 3 & Biochips & 2 & & \\
\hline & $\begin{array}{l}\text { Structural problems in } \\
\text { bioscience research }\end{array}$ & 2 & Allergy genes & 2 & & \\
\hline & Post-genome & 2 & Tailor-made medicine in dentistry & 1 & & \\
\hline & Personalized drug administration & 2 & $\begin{array}{l}\text { Ten-year general strategy } \\
\text { against cancer }\end{array}$ & 1 & & \\
\hline & Bioinformatics & 1 & $\begin{array}{l}\text { Amyotrophic lateral sclerosis } \\
\text { and tailor-made medicine }\end{array}$ & 1 & & \\
\hline & Anticancer drug sensitivity tests & I & Diabetes and tailor-made medicine & 1 & & \\
\hline & Future predictions & I & “Chronotherapy," in which & I & & \\
\hline & & & adverse effects are decreased & & & \\
\hline & & & with time of day medicine is taken & & & \\
\hline & Genetic discrimination & I & Advanced cancer screening & 1 & & \\
\hline & Comparison of accuracy with & I & Explanation of advanced medicine & I & & \\
\hline & Celera Genomics & & Use of genetic information & 1 & & \\
\hline \multirow[t]{18}{*}{$\begin{array}{l}\text { Articles on } \\
\text { research }\end{array}$} & Herceptin & 7 & $\begin{array}{l}\text { Gene bank (project to provide } \\
\text { medicine suited to individual } \\
\text { genetic information) }\end{array}$ & 11 & $\begin{array}{l}\text { Creation of muscular dystrophy } \\
\text { patient genetic information } \\
\text { database }\end{array}$ & 2 \\
\hline & DNA chip development & 4 & $\begin{array}{l}\text { Bipolar disorder and tailor- } \\
\text { made medicine }\end{array}$ & 5 & $\begin{array}{l}\text { Development of pathological } \\
\text { diagnosis center }\end{array}$ & I \\
\hline & ES cells & 2 & Lecture meeting guide & 3 & iPS cells & I \\
\hline & Celera Genomics research & 2 & $\begin{array}{l}\text { International standardization } \\
\text { of databases }\end{array}$ & 2 & Researcher profile & I \\
\hline & HIV and tailor-made medicine & 2 & Cancer society conferences & 2 & $\begin{array}{l}\text { Hepatitis } C \text { and tailor-made } \\
\text { medicine }\end{array}$ & I \\
\hline & DNA vaccine & 2 & Researcher profile & 2 & $\begin{array}{l}\text { New blood concentration } \\
\text { analysis methods } \\
\text { (theophylline, etc) }\end{array}$ & I \\
\hline & Irinotecan & 2 & $\begin{array}{l}\text { Industry-government-academia } \\
\text { joint projects }\end{array}$ & 2 & Drug design & I \\
\hline & Discovery of epilepsy gene & 2 & $\begin{array}{l}\text { Completion of genome } \\
\text { sequencing and future significance }\end{array}$ & 2 & Genes related to hepatitis B & 1 \\
\hline & $\begin{array}{l}\text { Bronchial asthma and tailor- } \\
\text { made medicine }\end{array}$ & 2 & Memory and genetic mutations & 2 & & \\
\hline & Human genome SNP identification & I & $\begin{array}{l}\text { Predicting efficacy of rheumatism } \\
\text { drugs using genes }\end{array}$ & I & & \\
\hline & $\begin{array}{l}\text { Genetic diagnosis of chronic } \\
\text { fatigue syndrome }\end{array}$ & I & $\begin{array}{l}\text { Predictions of survival following } \\
\text { lung cancer surgery }\end{array}$ & 1 & & \\
\hline & High blood pressure gene & I & Diabetes drugs and SNP & I & & \\
\hline & $\begin{array}{l}\text { Industry-government-academia } \\
\text { collaboration }\end{array}$ & I & $\begin{array}{l}\text { Kazusa Akademia Park, a biotechnology } \\
\text { center in Chiba Prefecture }\end{array}$ & 1 & & \\
\hline & $\begin{array}{l}\text { Esophageal cancer and } \\
\text { anticancer drugs }\end{array}$ & I & Bioventures originating at universities & 1 & & \\
\hline & $\begin{array}{l}\text { Development of gene } \\
\text { analysis systems }\end{array}$ & I & $\begin{array}{l}\text { New drug development and start } \\
\text { of clinical trials }\end{array}$ & 1 & & \\
\hline & $\begin{array}{l}\text { Tailor-made medicine for } \\
\text { atomic bomb survivors }\end{array}$ & I & $\begin{array}{l}\text { Establishment of specialized } \\
\text { courses }\end{array}$ & I & & \\
\hline & Hepatitis $C$ research & I & Regenerative medicine & I & & \\
\hline & $\begin{array}{l}\text { Methods of detecting individual } \\
\text { differences in genetic information }\end{array}$ & 1 & Protein analysis & 1 & & \\
\hline
\end{tabular}


Table 2 (Continued)

\begin{tabular}{|c|c|c|c|c|c|c|}
\hline Classification & Detailed classification $200 \mathrm{I}$ & $\mathbf{n}$ & Detailed classification 2003 & $\mathbf{n}$ & Detailed classification 2009 & $\mathbf{n}$ \\
\hline & Biotechnology and & I & Current status of anticancer agent use & I & & \\
\hline & Foundation of translational & I & & & & \\
\hline & research centers & & & & & \\
\hline & Researcher profile & 1 & & & & \\
\hline & Problems in bioscience research & I & & & & \\
\hline & MDRI protein gene & I & & & & \\
\hline \multirow{22}{*}{$\begin{array}{l}\text { Articles on } \\
\text { companies }\end{array}$} & Corporate collaboration & 5 & DNA chips & 7 & Corporate researcher profile & I \\
\hline & DNA chips & 4 & Bioventures & 3 & & \\
\hline & $\begin{array}{l}\text { Other businesses enter genome } \\
\text { medicine market }\end{array}$ & 2 & $\begin{array}{l}\text { Development of DNA } \\
\text { synthesis and } \\
\text { detection devices }\end{array}$ & 2 & & \\
\hline & $\begin{array}{l}\text { Foreign manufacturers market } \\
\text { new anticancer drugs in Japan }\end{array}$ & 2 & Business manager lectures & 2 & & \\
\hline & Establishment of corporate & 2 & Corporate restructuring & 2 & & \\
\hline & genome research center & & & & & \\
\hline & Bioventures & 2 & $\begin{array}{l}\text { Research not advancing at genomic } \\
\text { medicine information analysis } \\
\text { center (Kobe) }\end{array}$ & 2 & & \\
\hline & Personnel rotation at Olympus & 2 & Corporate researcher profile & 1 & & \\
\hline & Comparison of drug industry & I & Gene function analysis system & I & & \\
\hline & in other countries and Japan & & & & & \\
\hline & Development of new drugs & I & Gene analysis for type of leukemia & 1 & & \\
\hline & for lifestyle-related diseases & & & & & \\
\hline & Start of gene analysis services & I & $\begin{array}{l}\text { Establishment of corporate } \\
\text { research organizations }\end{array}$ & I & & \\
\hline & Sales of genome data by & I & Protein analyzers & I & & \\
\hline & Celera Genomics & & & & & \\
\hline & Development of genetic & 1 & Establishment of new & 1 & & \\
\hline & information databases & & research centers & & & \\
\hline & & & SNP analysis for gastrointestinal drugs & I & & \\
\hline & & & Personnel rotation & I & & \\
\hline & & & Company president interviews & I & & \\
\hline & & & Growth strategy & I & & \\
\hline & & & Establishment of new companies & I & & \\
\hline Lecture & Tailor-made medicine & 8 & Tailor-made medicine & 13 & General science & 2 \\
\hline presentations & Bioscience in general & 3 & Nanotechnology and bioscience & 1 & Bioscience & I \\
\hline \multirow{10}{*}{$\begin{array}{l}\text { National } \\
\text { strategy }\end{array}$} & Budget & 3 & Anti-cancer strategy & 3 & Medical Engineering Technology & I \\
\hline & & & & & $\begin{array}{l}\text { Industrial Strategy Consortium } \\
\text { (METIS) }\end{array}$ & \\
\hline & Promotion of genomic medicine & 2 & Budget & 2 & & \\
\hline & Promotion of cooperation & 2 & Cooperative projects with & I & & \\
\hline & between medicine and engineering & & nanotechnology ministries and agencies & & & \\
\hline & $\begin{array}{l}\text { Key government policies in } \\
\text { each country }\end{array}$ & I & & & & \\
\hline & Proposed general plan of the & I & & & & \\
\hline & Council for Science and & & & & & \\
\hline & Technology Policy, Cabinet Office & & & & & \\
\hline & $\begin{array}{l}\text { Financial support for advanced } \\
\text { technologies }\end{array}$ & I & & & & \\
\hline \multirow[t]{5}{*}{ Problems } & Bioethics & 4 & Need for personal information & 2 & Problems with insurance system & I \\
\hline & & & protection in the field of medicine & & & \\
\hline & Concerns about human cloning & 3 & New drug review & 1 & & \\
\hline & Lack of human cell samples & I & Lack of bioinformatics specialists & I & & \\
\hline & Sharing of genetic information & I & Cancer screening standardization & I & & \\
\hline
\end{tabular}


Table 2 (Continued)

\begin{tabular}{|c|c|c|c|c|c|c|}
\hline Classification & Detailed classification 200 I & $\mathbf{n}$ & Detailed classification 2003 & $\mathbf{n}$ & Detailed classification 2009 & $\mathbf{n}$ \\
\hline & Differences in way of thinking & I & & & & \\
\hline & about bioethics in Japan and & & & & & \\
\hline & Western countries & & & & & \\
\hline \multirow[t]{5}{*}{ Book reviews } & Newspaper feature articles & $\mathrm{I}$ & Post-genome & $\mathrm{I}$ & Hospice & 2 \\
\hline & Problems of research & I & Individual differences in & $\mathrm{I}$ & & \\
\hline & in Japan & & drug effectiveness & & & \\
\hline & Full explanations of genome & I & & & & \\
\hline & research & & & & & \\
\hline
\end{tabular}

companies, and governments. ${ }^{25}$ We are planning future studies to investigate the roles these media play in the public dissemination of medical information. Social media, such as Twitter or Facebook, may also be worth investigating. Second, this study was limited to Japanese media. Media in English or other languages need to be investigated in future studies to determine how Japanese newspapers compare in terms of the reporting of genome-related articles. Third, only newspaper articles were included in this study. Significant differences in the coverage of medical issues have been reported between newspapers and television. ${ }^{12}$ This is possibly because different types of media attract different audiences. Genomic medicine is not a major health issue that is on the minds of the general public, especially when compared to issues such as obesity, smoking, or cancers, which have been the subject matter of previous reports..$^{12,15,21,26-28}$ Therefore, highly limited space was probably available for the issue of genomic medicine on television, making it difficult to provide detailed results as to why this discrepancy in news coverage exists. Further investigations about the role of this media are warranted. Additionally, it would be worthwhile to investigate advertising related to genomic medicine in future studies. Fourth, it may actually be appropriate for the media to have reported less upon genomic medicine than scientific journals, given the current stage of this area of research. To date, there are very few health conditions that have shown relevant pharmacogenetic treatment models or preventive medical practices, so it is reasonable that there is a lack of coverage in the press. We could argue that this lack of coverage exhibits appropriate restraint by the press. Fifth, we did not conduct a direct comparison using statistical models due to the difference in methods of detecting articles; however, differences in the trends of newspaper coverage and the number of academic journals itself provided enough useful and important information in this study. Sixth, in the last several years, the rapid expansion of "next-generation" sequencing is making genomic medicine a true reality. While our data is derived from just before the "next-generation" era, it is extremely likely that another increase in coverage in the press is currently occurring, and this transition may have been occurring beginning in 2010. The revolution that is being wrought by new technologies that make high-throughput sequencing a financial and logistical reality in many contexts may be influencing the coverage by the mass media. This issue is worth investigating in future studies. Seventh, another possible limitation of this study is that journalists may have used more lay language, including words such as "family history" or "risk;" therefore, there may have been some oversight when extracting data from newspaper articles.

The optimal strategy in sharing information on genomic medicine between scientists, physicians, and the lay public via the media is uncertain. Schnoll et al reported that the publication of information regarding the use of spiral computed tomography for early lung cancer detection ${ }^{27}$ did not increase the level of public awareness and interest, although lung cancer is one of the most important and widely mentioned cancers, with the general public having an intense interest in its prevention and detection. ${ }^{11}$ In contrast, genomic medicine is less well known than is cancer among the general public, although genetic medicine is expected to play an important role in the future. Thus, it is more difficult to increase the general public's level of awareness and interest in this topic. Although an optimal strategy of disseminating this information is still unknown, Schnoll et al ${ }^{27}$ provided an important clue. They showed that greater exposure of health news within magazines is related to greater awareness. Magazines can provide more detailed information in their health-related articles than newspapers. This kind of media can, potentially, also play an important role in communicating findings and information about genomic medicine. Internet media may also be a promising medium through which to present this information because there are no space constraints. 


\section{Conclusion}

The present study revealed a significant gap in the amount of information being presented about genomic medicine between newspaper coverage and scientific articles in academic journals. Sharing information about genomic medicine is crucial for the facilitation of personalized medicine in the future. Hence, scientists and medical professionals need to be aware of the features and structural characteristics of mass media when they disseminate information to the public.

\section{Acknowledgment}

This work was supported by a Grant-in-Aid from the Global Center of Excellence program of the Japan Society for the Promotion of Science.

\section{Disclosure}

The authors report no conflicts of interest in this work.

\section{References}

1. Lander ES, Linton LM, Birren B, et al; for International Human Genome Sequencing Consortium. Initial sequencing and analysis of the human genome. Nature. 2001;409(6822):860-921.

2. Venter JC, Adams MD, Myers EW, et al. The sequence of the human genome. Science. 2001;291(5507):1304-1351.

3. Collins FS. The case for a US prospective cohort study of genes and environment. Nature. 2004;429(6990):475-477.

4. Manolio TA, Bailey-Wilson JE, Collins FS. Genes, environment and the value of prospective cohort studies. Nat Rev Genet. 2006;7(10): $812-820$.

5. Hong KW, Oh B. Overview of personalized medicine in the disease genomic era. BMB Rep. 2010;43(10):643-648.

6. Ginsburg GS, Willard HF. Genomic and personalized medicine: foundations and applications. Transl Res. 2009;154(6):277-287.

7. Gonzalez-Angulo AM, Hennessy BT, Mills GB. Future of personalized medicine in oncology: a systems biology approach. J Clin Oncol. 2010; 28(16):2777-2783.

8. Giannoulis C, Botetzagias I, Skanavis C. Newspaper reporters' priorities and beliefs about environmental journalism: an application of Q-methodology. Sci Commun. 2010;32(4):425-466.

9. Takita M, Narimatsu H, Tomoko M, et al. Study of newspaper reports regarding clinical trials in Japan. J Clin Oncol. 2009;27(12): 2099-2101.

10. Mizuno Y, Narimatsu H, Kishi Y, et al. Structural problems of medical news reports in newspapers: a verification of news reports on an incident of mass nosocomial Serratia infection. J Infect Chemother. 2010;16(2): 107-112.

11. Downs A. Up and down with ecology-the "issue-attention cycle". Public Interest. 1972;28:38-50.

Risk Management and Healthcare Policy

\section{Publish your work in this journal}

Risk Management and Healthcare Policy is an international, peerreviewed, open access journal focusing on all aspects of public health, policy, and preventative measures to promote good health and improve morbidity and mortality in the population. The journal welcomes submitted papers covering original research, basic science, clinical \& epidemio-
12. Barry CL, Jarlenski M, Grob R, Schlesinger M, Gollust SE. News media framing of childhood obesity in the United States from 2000 to 2009. Pediatrics. 2011;128(1):132-145.

13. Moynihan R, Bero L, Ross-Degnan D, et al. Coverage by the news media of the benefits and risks of medications. $N$ Engl J Med. 2000; 342(22):1645-1650.

14. Brodie M, Hamel EC, Altman DE, Blendon RJ, Benson JM. Health news and the American public, 1996-2002. J Health Polit Policy Law. 2003;28(5):927-950.

15. Hawkins KW, Linvill DL. Public health framing of news regarding childhood obesity in the United States. Health Commun. 2010;25(8): 709-717.

16. Steele WR, Mebane F, Viswanath K, Solomon J. News media coverage of a women's health contraversy: how newspapers and TV outlets covered a recent debate over screening mammography. Women Health. 2005;41(3):83-97.

17. Taylor-Clark KA, Mebane FE, Steelfisher GK, Blendon RJ. News of disparity: content analysis of news coverage of African American healthcare inequalities in the USA, 1994-2004. Soc Sci Med. 2007; 65(3):405-417.

18. Tong A, Chapman S, Sainsbury P, Craig JC. An analysis of media coverage on the prevention and early detection of CKD in Australia. Am J Kidney Dis. 2008;52(1):159-170.

19. Slater MD, Long M, Bettinghaus EP, Reineke JB. News coverage of cancer in the United States: a national sample of newspapers, television, and magazines. J Health Commun. 2008;13(6):523-537.

20. Slater MD, Long M, Ford VL. Alcohol, illegal drugs, violent crime, and traffic-related and other unintended injuries in US local and national news. J Stud Alcohol. 2006;67(6):904-910.

21. Schwartz LM, Woloshin S. News media coverage of screening mammography for women in their 40s and tamoxifen for primary prevention of breast cancer. JAMA. 2002;287(23):3136-3142.

22. Long M, Slater MD, Lysengen L. US news media coverage of tobacco control issues. Tob Control. 2006;15(5):367-372.

23. Suleski J, Ibaraki M. Scientists are talking, but mostly to each other: a quantitative analysis of research represented in mass media. Public Underst Sci. 2009;19(1):115-125.

24. adv.yomiuri [homepage on the Internet]. Advertising guide. Tokyo: Yomiuri Shimbun [cited February 14, 2011]. Available from: http:// adv.yomiuri.co.jp/yomiuri/busu/busu01.html. Accessed February 14, 2011. Japanese.

25. Narimatsu H, Hori A, Matsumura T, et al. Cooperative relationship between pharmaceutical companies, academia, and media explains sharp decrease in frequency of pulmonary complications after bortezomib in Japan. J Clin Oncol. 2008;26(35):5820-5823.

26. Kang S, Gearhart S, Bae HS. Coverage of Alzheimer's disease from 1984 to 2008 in television news and information talk shows in the United States: an analysis of news framing. Am JAlzheimers Dis Other Demen. 2010;25(8):687-697.

27. Schnoll RA, Wileyto EP, Hornik R, Schiller J, Lerman C. Spiral computed tomography and lung cancer: science, the media, and public opinion. J Clin Oncol. 2007;25(36):5695-5697.

28. Audrain-McGovern J, Tercyak KP, Shields AE, Bush A, Espinel CF, Lerman C. Which adolescents are most receptive to tobacco industry marketing? implications for counter-advertising campaigns. Health Commun. 2003;15(4):499-513.

29. Itty S, Pulido JS. Rituximab for intraocular lymphoma. Retina. Feb 2009;29(2):129-132.

logical studies, reviews and evaluations, guidelines, expert opinion and commentary, case reports and extended reports. The manuscript management system is completely online and includes a very quick and fair peerreview system, which is all easy to use. Visit http://www.dovepress.com/ testimonials.php to read real quotes from published authors. 